УДК [001.8:004.77]:37.011.3

\author{
Орап Марина Олегівна \\ доктор психологічних наук, доцент, доцент кафедри психології \\ Тернопільський національний педагогічний університет імені Володимира Гнатюка, \\ м. Тернопіль, Україна \\ ORCID ID 0000-0001-7598-8453 \\ orap2003@ukr.net
}

\title{
ВПЛИВ ІНТЕРНЕТ РЕСУРСІВ НА ЗМІСТОВІ ХАРАКТЕРИСТИКИ МОВЛЕННЄВОГО ДОСВІДУ ДІТЕЙ МОЛОДШОГО ШКІЛЬНОГО ВІКУ
}

\begin{abstract}
Анотація. У статті представлено результати теоретичного й емпіричного дослідження впливу інформаційно-комунікаційних технологій (ІКТ) на мовленнєвий досвід дітей молодшого шкільного віку, виявлено напрями подальших досліджень впливу мережі Інтернет середовища на мовленнєвий досвід. Визначено проблему, що полягає у недостатньому врахуванні у педагогічному процесі нецілеспрямованого і неорганізованого використання дітьми інформаційно-комунікаційних технологій. 3'ясовано основні теоретичні підходи до вивчення проблеми взаємодії дітей і Інтернет-середовища та основні напрями використання IКТ у педагогічному процесі. Критичне осмислення наукових теоретичних та практичних розвідок дало змогу виокремити потребу вивчення питання впливу інформаційних ресурсів мережі Інтернет на змістові характеристики мовленнєвого досвіду дітей молодшого шкільного віку. У статті обгрунтовано підхід до вивчення мовлення саме як до мовленнєвого досвіду, докладно описано методику емпіричного дослідження. Дослідження здійснюється в парадигмі теорії мовленнєвого досвіду, згідно 3 якою останній розглядається як система у свідомості особистості, спрямована на здійснення мовленнєвого освоєння особистістю світу. Зовнішня структура мовленнєвого досвіду, котра складається з мовленнєвої компетентності, мовної картини світу та мовленнєвої культури, виконує функцію опосередкування мовленнєвої взаємодії дитини із світом. У статті визначено провідні функції кожного елементу мовленнєвого досвіду, змістові характеристики та маркери, а також діагностичний інструментарій, за допомогою якого виявляються ці маркери. У результаті здійсненого емпіричного дослідження було виокремлено специфічні змістові характеристики мовленнєвого досвіду дітей молодшого шкільного віку, зумовлені використанням IКТ: збільшення асортименту та диференціації емоцій одночасно зі зменшенням здатності до їх вербалізації; переважання динамічних фреймових когнітивних структур над статичними; розширення семантичних полів; збільшення ініціативності в комунікації; зменшення ролі правильності мовлення, дотримання граматичних і синтаксичних норм мови; збільшення семантичної гнучкості. Провідним висновком здійсненого дослідження є те, що використання ІКТ здійснює вплив не лише на кількісні показники мовленнєвого досвіду дітей молодшого шкільного віку (рівень мовленнєвого розвитку), а змінює його змістові характеристики.
\end{abstract}

Ключові слова: інформаційно-комунікаційні технології; спілкування; мовлення; Інтернет; мовленнєвий досвід; діти молодшого шкільного віку.

\section{1. ВСТУП}

Сьогодення ясно демонструє, що подальше життя людства невіддільне від використання новітніх інформаційно-комунікаційних технологій (IКТ) і неможливе без них. Використання мережі Інтернет та цифрових технологій змінює не тільки суспільство, а й тип культури i, відповідно, тип освіти як засіб передачі цієї культури наступним поколінням. Сама ж культура під впливом інформатизації стає моментом інформаційного поля, виходить із національного i потрапляє в універсальне інформаційне середовище, відбувається глобалізація, асиміляція. У сучасному середовищі людина постійно занурена в це універсальне інформаційне середовище, і це 
істотно змінює закономірності розвитку і функціонування особистості. Це спричинило до того, що, як зазначає С. Семчук, психосоціальна система «соціум - особистість» у наш час поступово набула принципово нової структури і якості. До неї активно долучився такий впливовий посередник, як мас-медіа, і відтепер діада «соціум особистість» виглядає як тріада «соціум - мас-медіа - особистість» [1, с. 322]. Отже, процес соціалізації відбувається як медіасоціалізація. Саме тому останнім часом багато вчених-соціологів, культурологів, педагогів, психологів, медичних працівників цікавляться цією проблемою та аналізують медіасоціалізуючий вплив інформаційнокомп'ютерних технологій на становлення особистості дитини молодшого шкільного віку.

До сучасних засобів IКТ навчання зараховують офісне та спеціалізоване програмне забезпечення, системи комп'ютерного супроводу та дистанційного навчання, мультимедійні електронні освітні ресурси, зокрема електронні посібники та підручники. Використання цих технологій у навчальному процесі тепер є невіддільним елементом життя, а відтак, соціалізації дитини, а не просто прагненням освіти йти в ногу з часом. Проте активне використання ІКТ істотно змінює не лише систему освіти та методику викладання предметів. Перш за все воно докорінно змінює закономірності формування і розвитку психічних процесів та властивостей дітей. I в цьому питанні в науці спостерігається певний дисбаланс - дидактика і методика активно розробляють $\mathrm{i}$ впроваджують новітні технології навчання 3 використанням IКТ водночас 3 недостатнім урахуванням особливостей психічного розвитку дитини в новітніх суспільних, культурних та освітніх умовах. Ми не можемо здійснити адекватні реформи в системі освіти без з'ясування того, як саме інформатизація суспільства та новітній тип інформаційної культури змінюють закономірності, особливості, функціональні можливості та завдання психічних процесів, станів та властивостей особистості. Саме тому педагогічним та методичним інноваціям повинні передувати психологічні дослідження змін психіки і свідомості дитини, спричинених новітніми соціокультурними умовами і використанням інформаційно-комунікаційних технологій зокрема.

Постановка проблеми. Науковці, психологи і педагоги, вчителі й методисти, батьки, вихователі намагаються знайти нові оптимальні, ефективні шляхи навчання i виховання дітей у новітніх соціальних умовах, впроваджують нові інтерактивні засоби навчання, способи і стилі викладання тощо. У педагогічній літературі ІКТ розглядають першочергово як засіб навчання, методичний прийом, який дає змогу швидше, ефективніше та більш наочно представити матеріал, удосконалити навички самостійної пошуково-пізнавальної діяльності, здійснити контроль та оцінку якості знань учнів [2], [3], [4].

В Інституті інформаційних технологій і засобів навчання АПН України розпочато цикл досліджень, метою яких $\epsilon$ вивчення впливу засобів IКТ, які $є$ постійними складовими навчального середовища початкової школи та активно використовуються в навчально-виховному процесі, на результати навчання та формування психічних якостей дитини. Попередні висновки, зроблені на основі результатів експериментального дослідження та їх математичного опрацювання, надають можливість констатувати, що використання засобів IКТ: не впливає на формування рівня здатності до перцептивних дій та формування рівня образної уяви; позитивно впливає на формування рівня здатності до абстрагування, на формування здатності до побудови внутрішнього плану дій та на рівень розвитку мовленнєвих характеристик, що супроводжують процес мислення. У процесі експериментального дослідження була визначена залежність результатів формування психічних якостей учнів молодших класів від якості дидактично орієнтованих засобів IКТ, методики їх використання та 
ступеня майстерності вчителів [5]. Проте, як зазначає у статті Ю.Жук, отримані результати характеризують зміни психічних процесів дітей після використання дидактично спрямованих засобів ІКТ, не враховуючи тих змін, котрі стаються стихійно, мимоволі, нецілеспрямовано під впливом самостійної взаємодії дитини 3 такими технологіями. Створена телебаченням та мережею Інтернет віртуальна реальність (медіареальність) є цілком конкурентоспроможною альтернативною дійсності, і разом вона утворює середовище існування сучасної дитини (медіасередовище). Очевидно, що сучасна дитина взаємодіє 3 медіасередовищем не лише, i не стільки в процесі організованого навчання, скільки в процесі стихійних, нецілеспрямованих впливів. Самостійне (і часто не контрольоване батьками і вчителями) використання мережі Інтернет для отримання нової інформації, спілкування та ігрової діяльності істотно впливає на зміни в процесі формування особистості. Це означує нам шлях та завдання дослідження, спрямованого на пошук загальних закономірностей особливостей розвитку та формування особистості дитини, зумовлених використанням новітніх ІКТ.

Аналіз останніх досліджень і публікацій демонструє, що в найбільш загальному вигляді дослідження проблеми взаємодії дитини та IКТ здійснюється в декількох основних напрямках.

Чимало сучасних науковців звертає увагу на небезпеку надмірного користування мережею Інтернет. Свого часу багато шуму наробила видана у США стаття Nicholas Carr "Is Google Making Us Stupid?" [6]. У ній автор грунтується на експерименті G. Small, директора Американського Центру дослідження Memory and Ageing Research Centre at the University of California, Los Angeles, з аналізу префронтальної мозкової активності внаслідок використання мережі Інтернет, порівнюючи ii у людей, які активно іiі використовують, та людей, які взагалі нею не користуються. Результати продемонстрували, що через шість днів одногодинного використання мережі Інтернет людьми, які до того нею не користувались, у них підвищувалась активність нейронів саме в тих ділянках мозку, які відповідають за короткочасну пам'ять та швидке прийняття рішень. Цим G. Small підкреслює пластичність мозку і те, що активізація одних ділянок мозку призводить до гальмування інших. Отже, із цього вже Nicholas Carr робить висновок, що Інтернет-середовище так сильно активізує частини мозку, які стосуються короткочасних і тимчасових речей, що глибоке мислення погіршується. Але цим можна пояснити і швидкість, з якою діти засвоюють інформацію з мережі Інтернет, i оперування більшою кількістю інформації і аргументів при прийнятті рішень.

Другий напрямок представлений науковими розвідками, котрі визначають Інтернет-середовище як позитивне, стимулююче та навчаюче середовище. У монографіï «Brain, Mind and Internet: a Deep History and Future» D. Staley наголошує на тому, що Інтернет як джерело знань побудований за іншим принципом, ніж книги, які були джерелом знань тривалий час до винаходу Інтернету [7]. Тому ознаками освіченої культурної людини була ієрархічна будова, лінійність і логічність когнітивних структур (за аналогією з будовою книги). I частково наш дискомфорт у взаємодії з Інтернетом може бути пов'язаний 3 тим, що він не побудований як ієрархічно впорядкована книжка. Проте Інтернет є репрезентативним простором, який забезпечує розмаїте семантичне поле асоціацій, а відтак «відображає наш недооцінений асоціативний мозок» [7, с. 32]. Інтернет не притупив нашу думку, але замість цього актуалізував раніше невикористовувану частину нашої когнітивної архітектури. Подібну думку висловлює i J. Brockman, наголошуючи на тому, що мова не йде про кращий чи гірший інтелект, а про різні способи розв'язання мислительних задач [8].

Водночас учений О. Зінченко підкреслює, що існує викривлення життєвих уявлень щодо користування Інтернетом у підлітковому віці. Здійснене вченим дослідження не виявило жодного адикта в інтервалі 13-15 років [9]. Як зазначає А. 
Войскунський, якщо інтернет-залежність існує, то кількість справді інтернет-залежних людей є невеликою [10]. Слід наголосити на тій групі досліджень, які вивчають зміни психіки дитини, спричинені впливом новітніх IКТ технологій. Американські вчені ще в 1961 році дійшли висновку, що перегляд медіапрограм прискорює розвиток дитини на рік, особливо до того часу, коли вона має йти до школи [11]. Сутність їхньої теорії полягає в тому, що молоде покоління на «комп'ютерних» зразках навчається міркувати, отримуює знання, розширює світогляд. Робота 3 комп'ютером, 3 одного боку, призводить до розширення контактів, можливості обміну соціокультурними цінностями, набуття символічного досвіду, розвитку процесів навіювання. Але, 3 іншого боку, вона може призвести до «синдрому залежності» від комп'ютерних мереж, який сприяє звуженню інтересів, відлученню від реальності, залежності від комп'ютерних ігор, соціальної ізольованості, ослабленню емоційних реакцій та багатьом негативним наслідкам. Відтак, увагу науковців слід зосередити на питаннях адекватної та найбільш ефективної взаємодії дитини 3 інформаційними та комунікативними технологіями [12].

Слід виокремити групу психологічних та дидактико-методичних досліджень, які обгрунтовують та 3'ясовують умови використання IКТ у сучасній освіті. Вітчизняні та закордонні дослідження з використання комп'ютера в освітніх закладах переконливо доводять не тільки можливість, але й доцільність використання комп'ютера та Інтернет-ресурсів, а також визначають особливу його роль у розвитку інтелекту i особистості дитини загалом [13], [14], [15], [16], [17].

Аналіз нових наукових джерел $з$ питань впливу IКT на дітей дошкільного віку дозволив виділити психологічні закономірності та особливості формування дитячої свідомості: підтримка уваги та зацікавленість дітей гострим сюжетом; підвищення уваги до перегляду коротких сюжетних роликів; можливість залучення дитини до участі в процесі перегляду реклами; захоплення дитини рекламним сюжетом базується на психологічних механізмах; легкість запам'ятовування короткого, цікавого та близького дитині сюжету; можливість формування в дитинстві етичних та моральних норм, цінностей за допомогою цікавого та доступного дитині сюжету [1]. Проте ми не зустрічаємо таких досліджень стосовно дітей молодшого шкільного віку.

Невирішені аспекти проблеми. Окремий значний напрям досліджень складають дослідження того, як саме новітні IК технології впливають на комунікацію, спілкування та мовлення. На думку Н.Акімової, загалом гуманітарний підхід до вивчення Інтернетмережі можна розглядати за трьома напрямками: 1) «Інтернет як медіа» - комунікативне середовище мережі сприяє появі і зумовлює формування нових культурних парадигм; 2) «Інтернет як мова» - поява та функціонування нових мовних систем; 3) «Інтернет як специфічне співтовариство» - побутування різноманітних фан-клубів, блог-товариств тощо [18, с. 12]. Учені досліджують особливості, специфічні властивості мови, яка утворюється в результаті спілкування в мережі Інтернет. Вона поступово переходить із віртуального світу в реальний, із жаргонізмів і сленгу - в літературні норми [19]. Л. Стрельбіцька наголошує на тому, що «компуторний жаргон - це нова підсистема української мови» [20, с. 38]. Це і справді вже певна система, оскільки має власні принципи функціонування, кодифікацію (створено словники як комп'ютерної лексики, так і словнички-рятівнички для відвідувачів блогів, форумів, чатів).

Учені висловлюють думку про те, що Інтернет спілкування не змінює докорінно стиль і способи спілкування, а лише актуалізує ті його особливості, котрі були наявні й раніше, але в меншому обсязі (до прикладу, використання абревіатур, скорочення слів чи збільшення кількості пунктуаційних знаків для вираження емоційного стану) [21, с. 57]. Виявлено, що Інтернет не робить спілкування більш формальним чи короткотривалим [22], [23], [24]. Проте, на нашу думку, найбільш загальною ознакою, 
найбільшою зміною, що істотно впливає на особливості сучасної комунікації, $є$ зазначене Morton A. Gernsbacher переважання писемного мовлення над усним, відтак переважання тексту над дискурсом. «Таким чином, найбільший вплив Інтернет справляє на те, як ми спілкуємось - це вияв нашої схильності більш до письма, ніж до усного мовлення. Чому? Я передбачаю, що це переважання писемної комунікації випливає із фундаментальної характеристики письма. Воно переважно асинхронне. На противагу говорінню, яке переважно $є$ синхронним, коли розмовляємо віч-на-віч або телефоном. Існує набагато більше форм асинхронної писемної комунікації, ніж асинхронного говоріння. Ця асинхронність письма, як я передбачаю, лежить в основі переважання письма над говорінням, що й виявляється у Інтернеті» [25, с. 370].

Отже, як зазначають науковці, Інтернет робить спілкування більш доступним, збільшує частку цього виду діяльності в житті людини, змінює знаряддя комунікації. Автори констатують, що відбувається зміна переважаючих видів мовленнєвої діяльності, через які люди обмінюються інформацією. На перший план у комунікації в зв'язку з використанням інформаційних технологій виходять письмо і читання, а усне мовлення й аудіювання відходять на другий план. Та й самі мовленнєві повідомлення зазнають значних трансформацій - стають більш згорнутими, формалізованими, i, водночас, інформативними, емоційно насиченими [26, с. 139].

Лінгводидактичні аспекти використання ІКТ активно обговорюються в науковопрактичній літературі. Зокрема, як зазначає Г. Корицька, «останнім часом учителі української все активніше використовують у навчально-виховному процесі вебтехнології, які виводять педагога й учня на партнерський рівень спілкування, надають можливість кожному школяреві проявити власну активність і творчість, забезпечують індивідуалізацію й диференціацію навчання» [27, с.45]. Введений ученим О. Гарцовим термін «електронна лінгводидактика» позначає теорію i практику використання електронних засобів у навчанні мови. Ученими активно розробляються дидактичні принципи «електронного навчання», створюються засади хмаро орієнтованого навчального середовища та веб-квест технології. Проте питання зміни психологічних закономірностей формування та розвитку мовлення, мовленнєвої діяльності та мовленнєвого досвіду дітей під впливом ІКТ залишається поза увагою науковців. Це й спонукало нас до проведення дослідження в цьому напрямку.

Метою статті $\epsilon$ аналіз теоретичних та емпіричних результатів дослідження впливу інформаційних ресурсів мережі Інтернет на змістові характеристики мовленнєвого досвіду дітей молодшого шкільного віку та з'ясування на цій основі психолого-педагогічних умов оптимальної реалізації функцій мовленнєвого досвіду дітей молодшого шкільного віку в освітньому процесі.

\section{2. МЕТОДИ ДОСЛІДЖЕННЯ}

Функцію накопичення, інтерпретації та актуалізації шляхів мовленнєвого освоєння світу у свідомості суб' єкта виконує мовленнєвий досвід. Отже, дослідження ми здійснюємо в парадигмі теорії мовленнєвого досвіду, згідно з якою останній розглядається як система у свідомості особистості, спрямована на здійснення мовленнєвого освоєння особистістю світу, котра є процесом і продуктом накопичення, упорядкування та систематизації у мовленнєвій формі результатів такого освоєння [28]. Функціонування мовленнєвого досвіду забезпечується роботою двох структур внутрішньої і зовнішньої, кожна з яких має власні функції у мовленнєвому освоєнні світу дитиною.

Внутрішня структура мовленнєвого досвіду реалізує функцію закріплення, упорядкування i систематизації результатів мовленнєвого освоєння світу за 
посередництвом мовленнєвої здатності, мовленнєвих здібностей, мовленнєвої компетенції та мовленнєвої діяльності. Мовленнєва здатність створює передумови, мовленнєві здібності обумовлюють індивідуальні особливості закріплення мовних та мовленнєвих знань, мовленнєва компетенція впорядковує мовні та мовленнєві знання, мовленнєва діяльність формує та формулює думку засобами мови та способом мовлення. Зазначена чотирьохкомпонентна внутрішня структура системи мовленнєвого досвіду адекватна меті забезпечення формування внутрішнього змісту мовленнєвого освоєння особистістю світу [28].

Проте зовнішній вияв змісту внутрішньої структури не є прямим. Ми можемо лише робити висновок про рівень розвитку організації мовленнєвого досвіду за певними показниками вияву особливостей мовленнєвого досвіду у життєдіяльності особистості. Як було виявлено, такими показниками, іншими словами - системноописовими характеристиками, слугують елементи зовнішньої структури. Тож зовнішня структура мовленнєвого досвіду розглядається, з одного боку, як система елементів, у кожному з яких відображаються особливості всіх елементів внутрішньої структури, а 3 іншого боку, як система, яка опосередковує вияв внутрішньої структури мовленнєвого досвіду в життєдіяльності особистості. У такому аспекті мовленнєва компетентність відображає здатність до здійснення мовленнєвої взаємодії, $є$ певною базою, основою, без якої неможливе мовленнєве освоєння світу; мовна картина світу представляє рівень узагальнення та систематизації мовних та мовленнєвих знань для категоризації світу; мовленнєва культура характеризує використання мовних та мовленнєвих знань і вмінь для здійснення комунікації. Отже, змістом зовнішньої структури мовленнєвого досвіду одночасно $є$ вияв у ній елементів внутрішньої структури та здійснення процесу опосередкування мовленнєвого освоєння світу особистістю [28].

Мовленнєвий досвід характеризується змістовими та організаційними характеристиками. Рівень організації мовленнєвого досвіду визначається рівнем упорядкованої взаємодії елементів внутрішньої та зовнішньої структури та оптимального розкриття їх функцій. Вияв залежності рівня організації мовленнєвого досвіду від ІКТ(ІК) технологій передбачає, насамперед, визначення специфічних характеристик такого впливу, які виявляються в змістовому наповненні елементів зовнішньої структури мовленнєвого досвіду. Отже, першочергово фокус дослідження був спрямований на вивчення тих змістових характеристик зовнішньої структури мовленнєвого досвіду, на які впливають особливості новітніх інформаційнокомунікаційних технологій. Ці характеристики були виявлені в результаті теоретичного аналізу та слугували підставою для означення маркерів та добору діагностичних методик, що відображено у таблиці 1.

Таблиия 1

Діагностичні показники змістових характеристик елементів зовнішньої структури мовленнсвого досвіду дітей молодшого шкільного віку

\begin{tabular}{|c|c|c|c|c|}
\hline & Функції & $\begin{array}{c}\text { Змістові } \\
\text { характеристики }\end{array}$ & Маркери & $\begin{array}{l}\text { Діагностичний } \\
\text { інструментарій }\end{array}$ \\
\hline $\begin{array}{l}\text { Мовленнєва } \\
\text { компетентність }\end{array}$ & $\begin{array}{l}\text { Інструментальна } \\
\text { (створення та } \\
\text { упорядкування } \\
\text { системи знань, } \\
\text { навичок та вмінь) }\end{array}$ & $\begin{array}{l}\text { Швидкість } \\
\text { реакції; } \\
\text { Обсяг } \\
\text { висловлювання; } \\
\text { Правильність } \\
\text { висловлювання. }\end{array}$ & $\begin{array}{l}\text { 1) рівень } \\
\text { дотримання } \\
\text { мовних правил } \\
\text { 2) пунктуаційна } \\
\text { грамотність } \\
\text { 3) середня } \\
\text { кількість слів у } \\
\text { реченні }\end{array}$ & $\begin{array}{l}\text { 1. Контент- } \\
\text { аналіз } \\
\text { письмових } \\
\text { повідомлень } \\
\text { 2. Метод аналізу } \\
\text { продуктів } \\
\text { діяльності } \\
\text { (диктант) }\end{array}$ \\
\hline
\end{tabular}




\begin{tabular}{|c|c|c|c|c|}
\hline $\begin{array}{l}\text { Мовна картина } \\
\text { світу }\end{array}$ & $\begin{array}{l}\text { Інтерпретаційна } \\
\text { (категоризація та } \\
\text { концептуалізація } \\
\text { знань) }\end{array}$ & $\begin{array}{l}\text { Особливості } \\
\text { мовних } \\
\text { когнітивних } \\
\text { структур; } \\
\text { Семантична } \\
\text { адекватність та } \\
\text { гнучкість. }\end{array}$ & $\begin{array}{l}\text { 1) } \\
\text { характеристики } \\
\text { асоціативних } \\
\text { реакцій } \\
\text { 2) } \\
\text { характеристики } \\
\text { фрейму } \\
\text { 3) семантична } \\
\text { гнучкість }\end{array}$ & $\begin{array}{l}\text { 1. Асоціативний } \\
\text { експеримент } \\
\text { 2. Фреймовий } \\
\text { аналіз }\end{array}$ \\
\hline $\begin{array}{l}\text { Мовленнєва } \\
\text { культура }\end{array}$ & $\begin{array}{l}\text { Комунікативна та } \\
\text { регулятивна } \\
\text { (мовленнєва } \\
\text { взаємодія) }\end{array}$ & $\begin{array}{l}\text { Емоційність; } \\
\text { Дотримання } \\
\text { правил } \\
\text { комунікації. }\end{array}$ & $\begin{array}{l}\text { 1) ініціативність } \\
\text { у комунікації } \\
\text { 2) } \\
\text { характеристики } \\
\text { мотивів } \\
\text { спілкування } \\
\text { 3) здатність } \\
\text { аналізувати } \\
\text { емоції } \\
\text { співбесідника }\end{array}$ & $\begin{array}{l}\text { 1. Методика } \\
\text { «Піктограма» } \\
\text { 2. Методика } \\
\text { репертуарних } \\
\text { решіток Келлі } \\
\text { 3. Анкетування }\end{array}$ \\
\hline
\end{tabular}

\section{3. РЕЗУЛЬТАТИ ДОСЛІДЖЕННЯ}

В емпіричному дослідженні взяли участь 297 дітей молодшого шкільного віку, учнів початкових класів шкіл міста Тернополя, середній вік - 8,5 років, 45,5\% хлопчиків та 54,5\% дівчаток.

Оскільки метою дослідження було не кількісне вираження мовленнєвого досвіду, а вияв специфічних змістових його характеристик, попереднє визначення рівня мовленнєвого розвитку дітей не здійснювалось. Кожна дитина обстежувалась за визначеними вище методиками, що дало можливість виявити спільні риси мовленнєвого досвіду, зумовлені впливом інформаційно-комунікаційних технологій.

1. Істотним результатом дослідження стала виявлена специфічність взаємодії дітей та емоцій у процесі Інтернет-спілкування: діти активно і дуже диференційовано використовували схематичні зображення емоцій (смайлики), розрізняючи смайли, наприклад, на означення радості і задоволення, посмішки і реготу, зніяковілості і задумливості, але мали значні труднощі в описі цих же емоцій словами $(83,3 \%)$. Діагностичні бесіди після тестування виявили недостатність лексичного запасу на позначення тих емоцій, які діти імпліцитно використовують у спілкуванні (ситуація «ну, я знаю, яка це емоція, але я не знаю як вона називається», «це коли мені соромно і незручно, і я червонію і не знаю, що сказати»). У цьому плані таке спілкування демонструє прекрасні можливості для вчителів і батьків у напрямку вербалізації емоцій, усвідомленої взаємодії з ними, а отже, до розвитку емоційного інтелекту.

2. Інформаційно-комунікаційні технології змінюють співвідношення когнітивних структур представлення знань. У 70-х роках минулого століття дослідники визначили, що переважаючою, провідною структурою $\epsilon$ фрейм як структура, пов'язана 3 повторюваними ситуаціями та відтворена лінгвістично у лексичних зв'язках між словами у реченні чи синтагмі. М. Мінський розглядав фрейми-образи і фреймисценарії, втім, не наголошуючи на різниці між ними. Проте подальші дослідження чітко розрізняють статичні і динамічні фрейми, наголошуючи на тому, що статичні фрейми $\epsilon$ концептуальною основою когнітивної структури знань. Здійснене нами дослідження продемонструвало переважання саме динамічних фреймових структур (у 88,1\% респондентів). Фреймові структури містять багато слів на позначення руху і дії («йти», 
«бігти», «рухатись», «рости»), вони сконструйовані з урахуванням динаміки («а потім вона виросла») та характеризуються наявністю варіацій («а якщо вчительки у класі не буде, то буде практикант або студент»). Це, на нашу думку, спричинене переважанням зорових відчуттів у дітей, розвитком кліпового мислення. Тому структура знань у дітей динамічна, вона знаходиться в русі, і когнітивні уявлення, хоч і мають фіксовані межі, проте в цих межах досить рухливі.

3. Ми вважаємо, що в процесі Інтернет-комунікації відбувається розширення семантичних полів також і за рахунок прагнення передати письмово форму особливості дискурсу, умови комунікації (Хм-м-м... я задумався), а також намагання передати інтонаційний супровід висловлювання засобами писемного мовлення («А-y-y-ууууу!»). «Хайпити», «агритись», «хейтер»- кальки з англомовних слів, які водночас слугують $\mathrm{i}$ сприяють розширенню семантичних полів.

4. Зазвичай діти, пасивні у мовленнєвому реальному спілкуванні, зберігають цю пасивність і у віртуальному спілкуванні. Проте нами виявлено, що 66,6\% дітей з тих, котрі були охарактеризовані як «пасивні у спілкуванні», зазначали, що їм легше і цікавіше почати спілкуватись в Інтернет-середовищі («тому що так не страшно», «там можна говорити про все»). Крім того, як зазначали учні, в Інтернет-середовищі вони часто беруть пасивну участь у розмовах, читаючи переписку в чаті, але не висловлюючи власних думок. Така ситуація неможлива в реальному спілкуванні, де дітей, які просто спостерігають за іграми чи розмовами, уникають. Тож ситуація Інтернет-спілкування підвищує ініціативність дитини.

5. Зменшення ролі правильності мовлення, дотримання граматичних та синтаксичних норм мови. Такий висновок зроблено на основі порівняння рівня грамотності в диктантах, які діти писали на уроці та висловлюваннях у міжособистому спілкуванні за допомогою мережних повідомлень. Аналіз демонструє, що діти знають правила пунктуації (89,7\% дітей адекватно і функціонально доречно використовують розділові знаки). Проте лише $30,4 \%$ респондентів використовують ці знаки у неформальному Інтернет-спілкуванні (перші слова речень не виділяються великими літерами, не використовуються коми, речення відділяються один від одного дужками або комами, емоційно забарвлені розділові знаки замінюються смайлами). У процесі бесіди з респондентами було виявлено, що лише 33,0\% дітей вважають розділові знаки істотними для організації розуміння повідомлення у процесі Інтернет-спілкування. Це дає підстави зробити висновок про те, що письмо як вид мовленнєвої діяльності у процесі Інтернет-комунікації для дітей молодшого шкільного віку $\epsilon$ менш формалізованим, не втрачаючи при цьому свого інформаційного та емоційного навантаження та змістової адекватності.

6. Маркерами збільшення семантичної гнучкості ми розглядаємо використання слів у незвичному для них значенні та мовленнєвому контексті, зміну їх комунікативного навантаження, вживання слів у новому контексті, надання їм нових смислів, що відрізняються від літературного та загальноприйнятого: створення абревіатур із найчастіше використовуваних усталених слів, форм звертання (на кшталт «Хз», «првт», «OMG»), уживання розмовно-фонетичного написання слів («ща», «тіко»).

Отже, специфічними змістовими характеристиками мовленнєвого досвіду дітей молодшого шкільного віку, зумовленими використанням комунікативноінформаційних технологій ми визначили:

1) збільшення асортименту та диференціації емоцій, одночасно із зменшенням здатності до їх вербалізації;

2) переважання динамічних фреймових когнітивних структур над статичними;

3) розширення семантичних полів;

4) збільшення ініціативності в комунікації; 
5) зменшення значення дотримання граматичних та синтаксичних норм мови в процесі Інтернет-спілкування;

6) збільшення семантичної гнучкості.

У результаті аналізу емпіричного матеріалу було виявлено, що основні зміни в зовнішній структурі мовленнєвого досвіду відбуваються в мовленнєвій компетентності та мовленнєвій культурі, мовна картина світу зазнає найменше змін. Інтернетспілкування змінює швидкість реакції на повідомлення, використання розділових знаків тощо. Автоматичне виправлення тексту, що здійснюється більшістю сучасних гаджетів, впливає на зниження значення грамотності в написанні та сприйманні повідомлень. Коми, крапки, три крапки замінюються смайликами та дужками. Відтак відбувається зміна змісту та ролі мовленнєвої культури та компетентності. Мовленнєвий досвід у зв'язку 3 інформаційно-комунікаційними технологіями рухається в напрямку збільшення адекватності й повноти відображення власної картини світу за зменшення ролі формальних розділових знаків та знання правил правопису в мовленнєвому спілкуванні.

Виокремлені специфічні характеристики зовнішньої структури мовленнєвого досвіду дітей молодшого шкільного віку дали змогу сформулювати психологопедагогічні рекомендації вчителям для найбільш оптимального використання особливостей інформаційно-комунікаційних технологій в освітньому процесі.

1. Ефективним шляхом удосконалення мовленнєвого досвіду в умовах використання IКТ є робота 3 вербалізації емоційних станів дітей, ознайомлення їх із назвами основних емоцій та їх відтінками. Як продемонструвало дослідження, ефективним у цьому буде робота 3 зіставлення графічного зображення емоцій («смайликів», «емоджі») із словами на позначення емоцій та почуттів. Вчителеві варто долучити до методичних прийомів і засобів завдання на опис словами певного «смайлика», створення розповіді про героя за допомогою «смайликів», рангування «смайликів», наприклад, від найвеселішого до найсумнішого, від розгніваного до задоволеного тощо.

2. Переважання динамічних фреймових структур над статичними окреслює завдання збалансування когнітивно-мовленнєвих структур через активізацію скрипт та схем. Використання відеосюжетів та комп'ютерних ігор з рухомими елементами зменшило здатність дітей тривалий час зосереджувати увагу на статичних елементах. Когніції, а відтак і мовлення, стали динамічними, швидкоплинними. У результаті це $\epsilon$ причиною негативних явищ дитячого мовлення - діти часто не завершують думку, розпочинають речення з середини думки, хвилюються, якщо швидко не можуть дібрати влучне слово, тож замінюють його словами-паразитами. Для відновлення балансу вчителеві варто звернути увагу на навчання дітей опису предмета, пейзажу, натюрморту тощо, вчити дітей виділяти й описувати деталі, адекватно реагувати на паузи в мовленні.

3. Доведеним $є$ той факт, що використання інформаційно-комунікаційних технологій в освіті підвищує навчальну мотивацію учнів, а отже робить навчальний процес більш інтенсивним і насиченим. Тож IКТ - прекрасний засіб для активізації мовленнєвої діяльності дітей молодшого шкільного віку. Саме в спілкуванні за допомогою комп'ютера, планшета чи смартфона в дітей зникають або зменшуються перешкоди, бар'єри в спілкуванні. Тому вчителеві початкової школи варто звернути увагу на використання ІКТ для збільшення ініціативності дітей у спілкуванні. Дієвим засобом цього можуть виступати групові чати, спільні обговорення навчальних тем засобами Інтернет-комунікації. За допомогою цих прийомів зростає й емоційний компонент соціального інтелекту дітей через оволодіння різними соціальними ролями, що $є$ істотним завданням початкової освіти. 


\section{4. ВИСНОВКИ ТА ПЕРСПЕКТИВИ ПОДАЛЬШИХ ДОСЛІДЖЕНЬ}

Провідним висновком здійсненого дослідження $€$ те, що використання інформаційно-комунікативних технологій здійснює вплив не лише на кількісні показники мовленнєвого досвіду дітей молодшого шкільного віку (рівень мовленнєвого розвитку), а й на його змістові характеристики. Збільшується ініціативність у спілкуванні, емоційна насиченість повідомлень, диференціація семантичних полів, відбувається використання слів у новому контексті (що створює передумови для семантичної гнучкості), створюється специфічний етикет Інтернет-спілкування. Водночас зменшується значення правильності, грамотності написання повідомлень, здатність до вербалізації емоцій та переживань, кількість та роль статичних когнітивних структур у функціонуванні мовної картини світу дітей. Здійснене дослідження дало змогу сформулювати психолого-педагогічні рекомендації для вчителів із організації взаємодії дітей з ІКТ, яке б найбільш оптимально сприяло удосконаленню мовленнєвого досвіду дітей молодшого шкільного віку.

Отже, подальші дослідження слід спрямувати на вивчення змін організації мовленнєвого досвіду дітей молодшого шкільного віку, спричинених інформаційнокомунікативними технологіями, а також на з'ясування педагогічних і методичних умов удосконалення змістових характеристик мовлення дітей 3 урахуванням виявлених психологічних закономірностей.

\section{СПИСОК ВИКОРИСТАНИХ ДЖЕРЕЛ}

[1] С. Семчук, "Медіасоціалізуючий вплив комп'ютерних технологій на молоде покоління", Збірник наукових прачь Уманського державного педагогічного університету імені Павла Тичини. Частина 3, c. $321-329,2014$.

[2] Т. І. Коваль, Підготовка викладачів вищяої иколи: інформаційні технології у педагогічній діяльності. К. : Вид. центр НЛУ, 2009.

[3] Е. М. Гудырева, "Внедрение информационно - коммуникативных технологий в учебный процесс высшего учебного заведения", Інформаційні технології в освіті, вип.6, с. 21-34, 2010.

[4] .В.Ставицька, "Інформаційно-комунікаційні технології в освіті", Матеріали науково-практичної конферениії, [Електронний ресурс]. Доступно : http://confesp.fl.kpi.ua/node/1103

[5] Ю. О. Жук, "Дослідження впливу інформаційних і комунікаційних технологій на формування особистісних якостей учнів загальноосвітніх навчальних закладів", Науково-методичний, інформаційно-освітній журнал "Вересень", № 1, с. 18-21, 2003.

[6] N. Carr, "Is Google making us stupid?", The Atlantic, July, p. 3 - 10, 2008.

[7] D. Staley, Brain, Mind and Internet: a Deep History and Future. Palgrave Pivot, 2014.

[8] J. Brockman, "How is the internet changing the way you think?", Edge, 2010. [Електронний ресурс]. Доступно: http://www.edge.org/annual-question/how-is-the-internet-changing-the-way-you-think

[9] О.В. Зінченко, "Емпіричне дослідження психологічних характеристик інтернет-спілкування у підлітковому віці", Проблеми сучасної психологї, вип. 29, с.43 - 58, 2015.

[10] А. Е. Войскунский, "Социальная перцепция в социальных сетях", Вестник Московского университета, Серия 14. Психология, №3, с. 90 - 104, 2014.

[11] W. Schramm, J. Lyle, E. B. Parker, Television in the Lives of Our Children. Stanford : Stanford University Press, 1961.

[12] L. Straker, C. Pollock, "Optimizing the interaction of children with information and communication technologies", Ergonomics, April 15, 48 (5), pp. 506 - 521, 2005.

[13] M. Sangra, M. Gonzalez-Sanmamed, "The role of information and communication technologies in improving teaching and learning processes in primary and secondary schools", Research in Learning Technology, Vol. 18., Issue 3., pp 207 - 220., 2010.

[14] C. Hall, C. N. Parton, S. Peckover, S. White, "Child-centric information and communication technology (ICT) and the fragmentation of child welfare practice in England", Journal of Social Policy, 39(3), pp. 393-413, 2010. 
[15] J. Tondeur, M. Valcke, J.Van Braak, "A multidimensional approach to determinants of computer use in primary education: teacher and school characteristics", Journal of Computer Assisted Learning, Volume 24, Issue 6, pp. $494-506,2008$.

[16] Г. В. Апостолова, "Про наслідки використання електронної техніки для розвитку здібностей дитини", Практична психологія та соичіальна робота, № 9-10, с. 1-3, 2003.

[17] Н. Д. Аль-Хамадані, "Вплив медіа-засобів на становлення особистості дитини дошкільного віку", Вісник ЛНУ імені Тараса Шевченка, № 13 (272), Ч. 1, с. 50 - 55, 2013.

[18] Н. В. Акімова, "Дослідження мови Інтернету: труднощі і перспективи", Нова філологія. Збірник наукових праць ЗНУ, №50. с.10-13, 2012.

[19] I. А. Ковальчук, "Мовна специфіка спілкування в інтернеті", Магістеріум. Мовознавчі студіi Національного університету «Києво-Могилянська академія», №2, с. 45-48, 2009.

[20] Л. Стрельбіцька, "Інтернет як полігон розвитку природної мови", Вісник Національного університету «Львівська політехніка» «Проблеми украӥнської термінологї̈», №538, с.33 - 38, 2005.

[21] Т. Н. Колокольцева, О. В. Лутовинова, Интернет-коммуникация как новая речевая формация, М. : ФЛИНТА : Наука, 2012.

[22] E. Arnett, "Technology has changed the way we communicate", News-Graphic, Aug 11; 2012. [Електронний ресурс]. Доступно: http://www.news-graphic.com/opinion/article_753cd746-e332-11e1955b-001a4bcf887a.html.

[23] .K. Chopra, "The effects of social media on how we speak and write", Social Media Today, Sep. 17, pp. $22-56,2013$.

[24] M. Leonardi, "Social media-communications perspective", News and Events: St Ambrose University. 2012 Jan; [Електронний ресурс]. Доступн: http://www.sau.edu/News_and_Events/N120125_Social_Media\%E2\%80\%93Communications_Perspecti ve.html

[25] M. A. Gernsbacher, "Internet-Based Communication", Discourse Process, 51(5-6), pp. 359-373, 2014.

[26] D. E. Madell, D.E., Muncer, "Control over social interactions: an important reason for young people's use of the Internet and mobile phones for communication", Cyberpsychology Behavior, Feb;10(1), pp. 137140, 2007.

[27] Г. Корицька, "Шкільна мовна освіта в умовах розвитку електронного навчального середовища", $E$ learning y теорї та практиці навчання суспільно-гуманітарних дисциплін: колективна монографія, за заг. ред. Г. Р. Корицької, Т. М. Путій, Івано-Франківськ, Україна: Симфонія форте, c. 40-54, 2017.

[28] М. О. Орап, Психологія мовленнєвого досвіду особистості, Тернопіль : Підручники і посібники, 2014.

Матеріал надійшов до редакиї 21.09.2018 p.

\title{
ВЛИЯНИЕ ИНТЕРНЕТ РЕСУРСОВ НА СОДЕРЖАТЕЛЬНЫЕ ХАРАКТЕРИСТИКИ РЕЧЕВОГО ОПЫТА ДЕТЕЙ МЛАДШЕГО ШКОЛЬНОГО ОПЫТА
}

\author{
Орап Марина Олеговна \\ доктор психологических наук, доцент, доцент кафедры психологии \\ Тернопольский национальный педагогический университет имени Владимира Гнатюка, г. Тернополь, \\ Украина \\ ORCID ID 0000-0001-7598-8453 \\ orap2003@ukr.net
}

Аннотация. В статье представлены результаты теоретического и эмпирического
исследования влияния информационно-коммуникационных технологий на речевой опыт
детей младшего школьного возраста, выявлены направления дальнейших исследований
влияния Интернет-среды на речевой опыт. Обозначена проблема, которая заключается в
недостаточном учете в педагогическом процессе нецеленаправленного и неорганизованного
использования детьми информационно-коммуникационных технологий. Определены
основные теоретические подходы к изуению проблемы взаимодействия детей и Интернет-
среды и основные направления использования ИКТ в педагогическом процессе.
Критическое осмысление научных теоретических и практических исследований позволило 
выделить необходимость изучения вопроса влияния информационных ресурсов Интернета на содержательные характеристики речевого опыта детей младшего школьного возраста. В статье обоснован подход к изучению речи именно как речевого опыта, подробно описана методика эмпирического исследования. Исследование осуществляется в парадигме теории речевого опыта, согласно которой последний рассматривается как система в сознании личности, направленная на осуществление речевого освоения личностью мира. Внешняя структура речевого опыта, которая состоит из речевой компетенции, языковой картины мира и речевой культуры, выполняет функцию опосредования речевого взаимодействия ребенка с миром. В статье определены ведущие функции каждого элемента речевого опыта, содержательные характеристики и маркеры, а также диагностический инструментарий, с помощью которого выявляются эти маркеры. В результате проведенного эмпирического исследования были выделены специфические содержательные характеристики речевого опыта детей младшего школьного возраста, обусловленные использованием ИКТ: увеличение ассортимента и дифференциации эмоций одновременно с уменьшением способности к их вербализации; преобладание динамических фреймовых когнитивных структур над статическими; расширение семантических полей; увеличение инициативности в коммуникации; уменьшение роли правильности речи, соблюдения грамматических и синтаксических норм языка; увеличение семантической гибкости. Основным выводом проведенного исследования является то, что использование ИКТ оказывает влияние не только на количественные показатели речевого опыта детей младшего школьного возраста (уровень речевого развития), а меняет его содержательные характеристики.

Ключевые слова: информационно-коммуникационные технологии; общение; речь; Интернет; речевой опыт; дети младшего школьного возраста.

\title{
THE INFLUENCE OF INTERNET RESOURCES ON YOUNG SCHOOL AGE CHILDREN'S SPEECH EXPERIENCE CONTENT CHARACTERISTICS
}

\author{
Maryna O. Orap \\ Doctor of Psychological Sciences, Associate Professor, Associate Professor of the Psychology Department \\ Ternopil Volodymyr Hnatiuk National Pedagogical University, Ternopil, Ukraine \\ ORCID ID 0000-0001-7598-8453 \\ orap2003@ukr.net
}

\begin{abstract}
The article presents the results of a theoretical and empirical study on the influence of information and communication technologies on the speech experience of young school age children as well as identifies the areas for further research on the influence of the Internet environment on speech experience. The author argues that unregulated and unorganized using of information and communication technologies by children in the pedagogical process has been studied insufficiently. The main theoretical approaches to studying the interaction between children and the Internet environment as well as the main directions of using information and communication technologies in the pedagogical process are determined. As a result of critical analysis of scientific theoretical and practical research, the author points out the need to study the influence of the Internet information resources on the content characteristics of the speech experience of young school age children. The article substantiates the approach to studying speech as speech experience. The methodology of empirical research is described in detail. The research supports the paradigm of speech experience theory, according to which speech experience is seen as a system in the mind of the individual aimed at speech mastering. The external structure of speech experience, which consists of speech competence, the language picture of the world and speech culture, performs a function of mediating speech interaction between the child and the world. The article defines the leading functions of each element of the speech experience, the content characteristics and markers, as well as the diagnostic tools used to identify these markers. As a result of the empirical study, specific content characteristics of the speech experience of children of young school age due to their use of communication and information technologies are determined. They include the concurrent increase in the range and differentiation of emotions on the one hand and the decrease in the ability to verbalize them on the other; the predominance of dynamic frame cognitive structures over static frames; the expansion of semantic fields; increasing initiative in communication; the reduction of the role of speech correctness, the observance of
\end{abstract}


grammatical and syntactic norms of the language; the increase in semantic flexibility. The main conclusion of the research is that the use of information and communication technologies affects not only the quantitative indicators of the speech experience of children of young school age (the level of speech development) but changes its content characteristics.

Keywords: information and communication technologies; communication; speech; the Internet; speech experience; children of young school age.

\section{REFERENCES (TRANSLATED AND TRANSLITERATED)}

[1] S. Semchuk, "Media-socializing influence of computer technologies on the younger generation", Bulletin of scientific works of Pavlo Tychyna Uman State Pedagogical University, Part 3, p. 321 - 329, 2014 (in Ukrainian).

[2] T. I. Koval, Training teachers of higher education: Information technologies in pedagogical activity, K: Publication center of NLU, 2009 (in Ukrainian).

[3] E. M. Gudyreva, "Implementation of information and communication technologies to the educational process of higher educational institution", Information Technologies in Education, Issue.6, p. 21-34, 2010 (in Russian).

[4] I. V. Stavytska, "Information and communication technologies in education", Materials of the scientific and practical conference, [Online]. Available: http://confesp.fl.kpi.ua/node/1103 (in Ukrainian).

[5] J. O. Zhuk, "Investigation of the influence of information and communication technologies on the formation of personality characteristics of students of general educational institutions", ScientificMethodical, Information and Educational Journal "September", № 1, p. 18-21, 2003 (in Ukrainian).

[6] N. Carr, "Is Google making us stupid?", The Atlantic, July, p. 3 - 10, 2008.

[7] D. Staley, Brain, Mind and Internet: a Deep History and Future. Palgrave Pivot, 2014.

[8] J. Brockman, "How is the internet changing the way you think?", Edge, 2010. [Online]. Available: http://www.edge.org/annual-question/how-is-the-internet-changing-the-way-you-think

[9] O. V. Zinchenko, "Empirical study of psychological characteristics of Internet communication in adolescence", Problems of modern psychology, № 29, p. 43 - 58, 2015 (in Ukrainian).

[10] A. E. Voiskunskii, "Social Perception in Social Networks", Moscow University Bulletin, Series 14. Psychology, №3, p. 90 - 104, 2014 (in Russian).

[11] W. Schramm, J. Lyle, and E. B. Parker, Television in the Lives of Our Children. Stanford: Stanford University Press, 1961.

[12] L. Straker, and C. Pollock, "Optimizing the interaction of children with information and communication technologies", Ergonomics, April 15, 48 (5), p. 506 - 521, 2005.

[13] M. Sangra, M. Gonzalez-Sanmamed, "The role of information and communication technologies in improving teaching and learning processes in primary and secondary schools", Research in Learning Technology, Vol. 18., Issue 3., p 207 - 220., 2010.

[14] C. Hall, C. N. Parton, S. Peckover, and S. White, "Child-centric information and communication technology (ICT) and the fragmentation of child welfare practice in England", Journal of Social Policy, 39(3), p. 393-413, 2010.

[15] J. Tondeur, M. Valcke, J.Van Braak, "A multidimensional approach to determinants of computer use in primary education: teacher and school characteristics", Journal of Computer Assisted Learning, Volume 24, Issue 6, p. $494-506,2008$.

[16] G. V. Apostolova, "About the effects of using the electronic technics for the development of child's abilities", Practical Psychology and Social Work, № 9-10, p. 1-3, 2003 (in Ukrainian).

[17] N. D. Al-Hamadani, "The influence of media on the formation of a preschooler child's personality", Bulletin of Taras Shevchenko National University of Lviv, № 13 (272), P. 1, p. 50 - 55, 2013 (in Ukrainian).

[18] N. V. Акімоva, "Internet language studies: challenges and prospects", New Philology. Collection of scientific works of ZNU, №50. p. 10-13, 2012 (in Ukrainian).

[19] I. A. Kovalchuk, "Language specificity of communication in the Internet", Magisterium. Linguistic studies of the National University "Kyiv-Mohylianska Academy", №2, p. 45-48, 2009 (in Ukrainian).

[20] L. Strelbitska, "Internet as a proving ground of natural language development", Bulletin of National University “Lvivska Politechnika» «The problems of Ukrainian terminology», №538, p.33 - 38, 2005 (in Ukrainian).

[21] T. N. Kolokoltseva, O. V. Lutovinova, Internet-communication as new speech formation, M.: FLINTA: Science, 2012 (in Russian). 
[22] E. Arnett, "Technology has changed the way we communicate", News-Graphic, Aug 11; 2012. [Online]. Available: http://www.news-graphic.com/opinion/article_753cd746-e332-11e1-955b-001a4bcf887a.html.

[23] K. Chopra, "The effects of social media on how we speak and write", Social Media Today, Sep. 17, p. 22 $-56,2013$.

[24] M. Leonardi, "Social media-communications perspective", News and Events: St Ambrose University. $2012 \quad$ Jan; [Online]. Available: http://www.sau.edu/News_and_Events/N120125_Social_Media\%E2\%80\%93Communications_Perspecti ve.html

[25] M. A. Gernsbacher, "Internet-Based Communication", Discourse Process, 51(5-6), p. 359-373, 2014.

[26] D. E. Madell, D.E., Muncer, "Control over social interactions: an important reason for young people's use of the Internet and mobile phones for communication", Cyberpsychology Behavior, Feb. 10(1), p. 137140, 2007.

[27] G. Korytska, "School language education in the context of the development of the e-learning environment", E-learning in the theory and practice of teaching social and humanitarian disciplines: a collective monograph. Ed. G. R. Korytska, and T. M. Putiy, Ivano-Frankivsk,: Symphonia Forte, p.40 54, 2017 (in Ukrainian).

[28] M. O. Orap, Psychology of the personality's speech experience, Ternopil : Pidruchnyky and Posibnyky, 2014 (in Ukrainian).

\section{(cc) BY-NC-SA}

This work is licensed under Creative Commons Attribution-NonCommercial-ShareAlike 4.0 International License. 